\title{
Soluble apoE/A $\beta$ complex: mechanism and therapeutic target for APOE4-induced AD risk
}

\author{
Leon M Tai ${ }^{1}$, Shipra Mehra ${ }^{1}$, Varsha Shete ${ }^{1}$, Steve Estus ${ }^{2}$, G William Rebeck ${ }^{3}$ Guojun Bu${ }^{4}$ and Mary Jo LaDu ${ }^{1 *}$
}

\begin{abstract}
The APOE4 allele of apolipoprotein $E(a p o E)$ is the greatest genetic risk factor for Alzheimer's disease (AD) compared to $A P O E 2$ and $A P O E 3$. Amyloid- $\beta(A \beta)$, particularly in a soluble oligomeric form $(O A \beta)$, is considered a proximal cause of neurodegeneration in AD. Emerging data indicate that levels of soluble $O A \beta$ are increased with $A P O E 4$, providing a potential mechanism of APOE4-induced AD risk. However, the pathway(s) by which apoE4 may increase oA are unclear and the subject of continued inquiry. In this editorial review, we present the hypothesis that apoE isoform-specific interactions with $A \beta$, namely apoE/A $\beta$ complex, modulate $A \beta$ levels. Specifically, we propose that compared to apoE3, apoE4-containing lipoproteins are less lipidated, leading to less stable apoE4/A $\beta$ complexes, resulting in reduced apoE4/A $\beta$ levels and increased accumulation, particularly of oA $\beta$. Evidence that support or counter this argument, as well as the therapeutic significance of this pathway to neurodegeneration, are discussed.
\end{abstract}

Keywords: Alzheimer's disease, Amyloid beta, Apolipoprotein E, Apolipoprotein E/amyloid beta complex, Oligomeric amyloid beta, Lipoprotein, Lipidation

\section{Introduction}

Sporadic Alzheimer's disease (AD) accounts for more than $95 \%$ of all $\mathrm{AD}$ cases and the APOE4 allele of apolipoprotein $\mathrm{E}$ (apoE) is the greatest genetic risk factor; two copies of the $A P O E 4$ allele increase AD risk up to 15 -fold relative to $A P O E 3$. APOE4 carriers account for more than half of $\mathrm{AD}$ patients and APOE4 accelerates onset of cognitive impairment by 7-9 years per allele $[1,2]$. The proposed mechanism(s) through which APOE4 increases $\mathrm{AD}$ risk are multifactorial, including both amyloid- $\beta(A \beta)$-dependent effects, i.e. modulation of $A \beta$ levels, aggregation, neurotoxicity and neuroinflammation, and $\mathrm{A} \beta$-independent effects, i.e. neuronal development, glucose metabolism, brain activity and lipid metabolism (reviewed in [3]). In this editorial review, we propose the hypothesis that apoE isoform-specific formation of soluble apoE/A $\beta$ complex modulates levels of neurotoxic $A \beta$, providing a basis for APOE4-induced AD risk. Therapeutic implications are presented, as well as arguments counter to this hypothesis.

\footnotetext{
* Correspondence: mladu@uic.edu

'Department of Anatomy and Cell Biology, University of Illinois at Chicago,

808 S. Wood St., M/C 512, Chicago, IL 60612, USA

Full list of author information is available at the end of the article
}

N.B.: For the purpose of this paper, $A \beta$ species will be identified with as much detail as allowed by the detection method of a specific publication i.e. "soluble A 342 " if measured in a soluble extraction fraction or soluble sample with an A 342 -specific ELISA or "soluble oA $\beta$ " if measured in a similar sample using an oligomer-specific detection method (for example, [4]). More general classes of $A \beta$ species will be referred to simply as $A \beta$ or soluble $A \beta$.

\section{Does $A P O E$ modulate soluble $A \beta$ levels?}

Genetic and experimental evidence posits soluble $A \beta$ as the proximal neurotoxin in AD. However, as a number of potentially neurotoxic forms of the $\mathrm{A} \beta$ peptide exist, the identity of the exact neurotoxic form of the peptide, if there is indeed only one, is unclear. The different forms of soluble $A \beta$ have ambiguous and often overlapping definitions based on the method of detection (e.g. biochemical or immunohistochemical analysis) and include; soluble $A \beta$ [5-7], oligomeric $A \beta$ (oA $\beta$ [8-11]) and $A \beta$ present in amyloid plaques [12-16]. Further complications include; 1) a dynamic compartmentalization between the different types of $A \beta$ in the CNS i.e. between plaques and soluble $A \beta[17,18]$; and 2) different forms of $A \beta$ contributing to neurodegeneration at different stages of the disease [19]. While plaque burden may not specifically correlate with 
cognitive dysfunction in $\mathrm{AD}$, an emerging consensus is that soluble $\mathrm{A} \beta 42$ and $\mathrm{oA} \beta$ represent major proximal, neurotoxic species in $\mathrm{AD}[15,20]$. Indeed, soluble $\mathrm{A} \beta$ and oA $\beta$ correlate with cognitive decline and disease severity in humans [21], and oA $\beta$ levels are associated with memory decline in transgenic mice expressing familialAD (FAD) mutations (FAD-Tg) (for review [21]).

In both FAD-Tg mice and humans, APOE4 is associated with higher levels of insoluble $A \beta$, the result of an increase in total plaque burden and extracellular $\mathrm{A} \beta$ compared to $A P O E 2$ and $A P O E 3$ [22-25]. Importantly, in FAD-Tg mice crossed with apoE-targeted replacement mice (apoE-TR), there are higher levels of both soluble A $\beta 42[12,23]$ and soluble oA $\beta$ (EFAD mice) [12], with APOE4 compared to $A P O E 3$. In addition, using a gene transfer approach, viral expression of $A P O E 4$ increases, and $A P O E 2$ decreases, ISF A 342 levels in FAD-Tg mice [18]. The increased soluble $\mathrm{A} \beta$ levels in FAD-Tg mice expressing APOE4 have been confirmed in humans $[4,26,27]$. In $\mathrm{AD}$ patients with $A P O E 4$ compared to $A P O E 3$, oA $\beta$ levels are higher surrounding amyloid plaques [26], in isolated synaptoneurosomes [26], synaptosome enriched extracts [28], and in TBS brain extracts [27]. Furthermore, in human $\mathrm{CSF}$, oA $\beta$ levels are increased in $\mathrm{AD}$ patients compared to non-AD (NAD) and are greater in APOE4/4 AD patients compared to $A P O E 3 / 3 \mathrm{AD}$ patients [4].

\section{Interpretation}

As soluble $\mathrm{A} \beta$ is considered a major neurotoxin in $\mathrm{AD}$, the apparent correlation between APOE4 and increased levels of particularly soluble oA $\beta$ suggests that understanding the underlying pathway(s) that mediates this effect may be critical to understanding the APOE4-induced risk for $\mathrm{AD}$. In turn, this fundamental biology could inform rational drug design and development of successful AD therapeutics.

\section{Does $A P O E$ modulate soluble apoE/A $\beta$ levels and stability?}

Historical perspective

ApoE isoform-specific effects on apoE/A $\beta$ complex levels may mediate the increased soluble $\mathrm{A} \beta$ and oA $\beta$ levels that correlate with $A P O E 4$. Research efforts to determine the effect of apoE isoform on in-vitro complex formation (Table 1) or in-vivo apoE/A $\beta$ complex levels (Table 2) have been ongoing for the last $\sim 20$ years (see Table 1 ). These studies demonstrate that the method of detection and the source of the components for apoE/A $\beta$ complex are critical parameters for experimental outcomes.

\section{Method of detection}

ApoE/A $\beta$ complex is defined by the method of detection, particularly the stringency of the assay conditions and the method used to isolate the in-vivo complex. Methods utilized to measure apoE/A $\beta$ complex, in order of decreasing stringency, include: gel-shift assay of SDS-PAGE (under reducing or non-reducing conditions), with Western blot analysis (WB) $[33,42,59,66,67]$; density gradient ultracentrifugation [68]; non-denaturing gradient gel electrophoresis [59]; co-immunoprecipitation (IP) [46]; size exclusion chromatography (SEC)/gel-filtration; and solidphase binding assays [29,38,45,47,51,69]. Using primarily SDS-PAGE or SEC-isolation followed by dot blot (DB) or WB (Table 1), apoE/A $\beta$ complex is detected when exogenous $A \beta$ is combined with apoE-containing lipoproteins from human plasma, CSF and cell culture supernatants. However, methods with relatively high stringency can result in disruption of the apoE/A $\beta$ complex, thus confounding interpretation of the data. The influence of assay stringency is highlighted by the effect of detergent during SDSPAGE with WB analysis; in-vitro SDS-stable apoE3/A $\beta$ levels are greater than apoE4/A $\beta$ [33], but comparable when analyzed by non-denaturing gel electrophoresis [59]. These data are consistent with an SDS-stable apoE3/A $\beta$ complex, and an apoE4/A $\beta$ complex that is disrupted by SDS (for review [56]). As well, the inclusion of a reducing agent during SDS-PAGE ( $\beta$-mercaptoethanol, $\beta$-ME; dithiothreitol, DTT) disrupts both the SDS-stable apoE3/A $\beta$ and apoE4/A $\beta$ complexes $[30,31,66]$.

For in-vivo apoE/A $\beta$ complex (Table 2), assay stringency also affects the levels of apoE/A $\beta$ complex. In-vivo apoE/A $\beta$ complex has been detected in the soluble fraction of human brain [46] and cerebrospinal fluid (CSF) $[53,63]$ by SEC isolation followed by $\mathrm{DB}$ or WB. The potential for in-vivo apoE/A $\beta$ complex to be disrupted by the method of detection was demonstrated in one of the earliest apoE/ $\mathrm{A} \beta$ complex studies by Russo and co-workers [46]. When analyzed by co-IP, soluble brain apoE/A $\beta$ complex levels were lower in $\mathrm{AD}$ compared to non-AD (NAD) patients. Importantly, complex from $\mathrm{AD}$ patients was less stable to SDS-PAGE with WB analysis and more susceptible to enzymatic degradation [46].

\section{Source of apoE/A $\beta$ complex}

ApoE is the major apolipoprotein present on CNS lipoproteins (for review [70]). In the CNS, apoE is produced primarily by glia (astrocytes and microglia), although under certain conditions neuronal apoE expression may occur [71]. Because apoE is an apolipoprotein, interactions with $A \beta$ depend on the lipidation state of the apoEcontaining lipoproteins (see below) i.e. whether the apoE is purified $[33,42,51,66]$, lipid-poor $[33,51,54]$, reconstituted with lipids from HDL [51], astrocyte-secreted [59], CSF-derived [29], or isolated plasma-lipoproteins [42,66,68]. Thus, evaluating the in-vitro interactions between apoE and $A \beta$ influenced by the source of apoE. For example, purified apoE4 binds $\mathrm{A} \beta$ with a higher affinity than 
Table 1 Effect of apoE isoform on soluble in-vitro apoE/A $\beta$ complex levels

\begin{tabular}{|c|c|c|c|c|c|}
\hline Study & Human apoE source & $A \beta$ source & $\begin{array}{l}\text { apoE:A } \beta \\
\text { Molar Ratio }\end{array}$ & Detection Method & Results \\
\hline \multirow[b]{2}{*}{$\begin{array}{l}\text { Strittmatter et al, } \\
\quad 1993[29,30]\end{array}$} & $\begin{array}{l}\text { Human CSF } \\
\text { (NAD \& AD) }\end{array}$ & $\begin{array}{l}\text { Syn. AB40, } \\
1-28,12-28\end{array}$ & $\begin{array}{c}* \\
(100 \mu \mathrm{ll} \text { CSF:2.5mM) }\end{array}$ & $\begin{array}{c}\text { SDS-PAGE } \\
\text { (Reducing), WB }\end{array}$ & apoE binds to $A \beta 40,1-28,12-28$ \\
\hline & Human plasma (Purified) & Syn. Aß40 & $1: 170$ & $\begin{array}{c}\text { SDS-PAGE } \\
\text { (Non-reducing), WB }\end{array}$ & 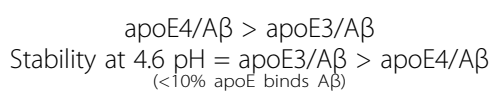 \\
\hline $\begin{array}{l}\text { Wisniewski et al, } \\
1993 \text { [31] }\end{array}$ & $\begin{array}{l}\text { Human CSF } \\
\text { (NAD \& AD) }\end{array}$ & $\begin{array}{l}\text { Syn. A } 340, \\
\text { A } 342\end{array}$ & 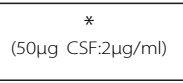 & $\begin{array}{c}\text { SDS-PAGE } \\
\text { (Reducing), WB }\end{array}$ & $\mathrm{apoE} / \mathrm{A} \beta$ at $34 \mathrm{kDa}$ \\
\hline $\begin{array}{l}\text { Sanan et al } \\
1994[32] \\
\end{array}$ & Human plasma (Purified) & Syn. Aß28 & $1: 139$ & $\begin{array}{c}\text { SDS-PAGE } \\
\text { (Non-reducing), WB }\end{array}$ & apoE3/A $\beta>$ > apoE4/A $\beta$ \\
\hline $\begin{array}{l}\text { LaDu et al, } \\
1994 \text { [33] }\end{array}$ & HEK293 (CM) & & & & apoE3/A $\beta$ > apoE4/A $\beta$ \\
\hline $\begin{array}{l}\text { LaDu et al, } \\
1995[34]\end{array}$ & $\begin{array}{l}\text { HEK293 (Purified \& CM), } \\
\text { Human plasma } \\
\text { (Native \& purified) }\end{array}$ & Syn. Aß40 & $1: 357$ & $\begin{array}{c}\text { SDS-PAGE } \\
\text { (Non-reducing), WB }\end{array}$ & 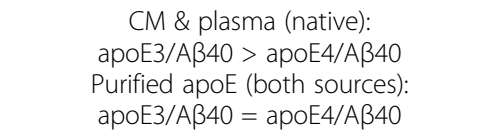 \\
\hline $\begin{array}{l}\text { Castano et al, } \\
1995[35]\end{array}$ & Recombinant ${ }^{\#}$ & Syn. Aß40 & $1: 169$ & $\begin{array}{c}\text { SDS-PAGE } \\
\text { (Non-reducing), WB }\end{array}$ & apoE3/Aß40 at 40kDa \\
\hline $\begin{array}{l}\text { Naslund et al, } \\
1995[36]\end{array}$ & Recombinant ${ }^{\#}$ & $\begin{array}{l}\text { Syn. } A \beta 40, \\
\text { A } \beta 42\end{array}$ & $1: 136$ & $\begin{array}{l}\text { SDS-PAGE } \\
\text { (Non-reducing \& } \\
\text { reducing), WB }\end{array}$ & $\begin{array}{l}\text { Non-reducing: apoE3/A } \beta=\text { apoE } 4 / A \beta \\
\text { Reducing: higher molecular mass } \\
\text { complexes }\end{array}$ \\
\hline $\begin{array}{l}\text { Golabek et al, } \\
1995 \text { [37] }\end{array}$ & Recombinant $\#$ & Syn. Aß40 & $1: 8.5$ & $\begin{array}{c}\text { SDS-PAGE } \\
\text { (Non-reducing), WB }\end{array}$ & apoE/A $\beta$ at $>36 \mathrm{kDa}$ \\
\hline $\begin{array}{c}\text { Golabek et al, } \\
1996[38]\end{array}$ & Recombinant ${ }^{\#}$ & Syn. Aß40 & 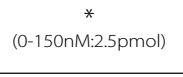 & Solid plate assay & $\mathrm{apoE} 2 / \mathrm{A} \beta=\mathrm{apoE} 3 / \mathrm{A} \beta=\mathrm{apoE} 4 / \mathrm{A} \beta$ \\
\hline $\begin{array}{c}\text { Shuvaev \& Siest et al, } \\
1996[39]\end{array}$ & Human plasma (Purified) & Syn. Aß40 & $1: 130$ & $\begin{array}{l}\text { Surface plasmon } \\
\text { resonance }\end{array}$ & $\begin{array}{c}\operatorname{apoE} 3 / A \beta>\text { apoEL4/A } \beta=a p o E 2 / A \beta \\
(\uparrow \text { apoE3/AB with } \uparrow \text { salt concentration \& } \\
\text { unaffected in pH } \mathrm{pH}-8)\end{array}$ \\
\hline $\begin{array}{l}\text { Chan et al, } \\
1996[40]\end{array}$ & $\begin{array}{c}\text { Ecoli (Purified), } \\
\text { Human plasma (Purified) }\end{array}$ & Syn. Aß40 & 1:3-1:11 & $\begin{array}{c}\text { SDS-PAGE } \\
\text { (Non-reducing), WB, Gel filtration }\end{array}$ & $\begin{array}{c}\text { apoE4/AB }=\text { apoE3/A } \beta=a p o E 2 / A \beta \\
\text { (Both sources gave same results, } A \beta \& \text { \& } \\
\text { apoE tetramer co-migrate) }\end{array}$ \\
\hline $\begin{array}{l}\text { Zhou et al, } \\
1996[41]\end{array}$ & RAW264 (CM) & Syn. Aß40 & $1: 170$ & $\begin{array}{c}\text { SDS-PAGE } \\
\text { (Non-reducing), WB }\end{array}$ & apoE3/A $\beta$ >> apoE4/A $(N D)$ \\
\hline
\end{tabular}


Table 1 Effect of apoE isoform on soluble in-vitro apoE/A $\beta$ complex levels (Continued)

\begin{tabular}{|c|c|c|c|c|c|}
\hline $\begin{array}{l}\text { LaDu et al, } \\
1997[42]\end{array}$ & $\begin{array}{c}\text { HEK293 (CM), } \\
\text { Human plasma } \\
\text { (Native \& Purified), rat \& } \\
\text { rabbit apoE (native) }\end{array}$ & Syn. A $\beta 40$ & $\begin{array}{l}1: 357(\mathrm{CM}) \\
1: 715 \\
\text { (Plasma) }\end{array}$ & $\begin{array}{c}\text { SDS-PAGE } \\
\text { (Non-reducing), WB }\end{array}$ & 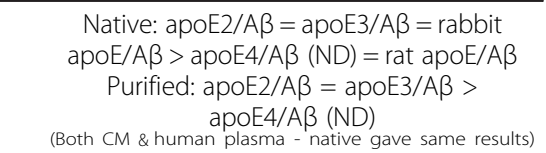 \\
\hline $\begin{array}{l}\text { Yang et al, } \\
1997[43]\end{array}$ & $\begin{array}{l}\text { CHO (CM), } \\
\text { Human plasma }\end{array}$ & Syn. A $\beta 40$ & $\begin{array}{l}\text { 1:97 (CM), } \\
\text { 1:850 } \\
\text { (Plasma) }\end{array}$ & $\begin{array}{c}\text { SDS-PAGE } \\
\text { (Non-reducing), WB }\end{array}$ & $\begin{array}{c}\text { apoE3/A } \beta=\text { apoE2/A } \beta>>\text { apoE } 4 / A \beta(N D) \\
\text { (Both sources gave same results) }\end{array}$ \\
\hline $\begin{array}{l}\text { Aleshkov et al, } \\
1997 \text { [44] }\end{array}$ & $\begin{array}{l}\text { BHK21 (CM), } \\
\text { Recombinant } \\
\text { (Lipidated), } \\
\text { Human plasma }\end{array}$ & Syn. A $\beta 40$ & 1:126 & $\begin{array}{c}\text { SDS-PAGE } \\
\text { (Non-reducing), WB }\end{array}$ & $\begin{array}{l}\text { Recombinant \& CM (apoE monomer): } \\
\text { apoE2/A } \beta>\text { apoE } 3 / A \beta>>\text { apoE } 4 / A \beta \\
\text { Plasma: apoE3/A }>\text { apoE } 4 / A \beta\end{array}$ \\
\hline $\begin{array}{l}\text { Pillot et al, } \\
1997[45]\end{array}$ & Recombinant ${ }^{\#}$ & $\begin{array}{l}\text { Syn. A } 329- \\
40 / 42\end{array}$ & 1:5-1:100 & $\begin{array}{c}\text { SDS-PAGE } \\
\text { (Non-reducing), WB }\end{array}$ & $\begin{array}{c}\text { apoE2/A } / A=\text { apoE3/A } \beta>\text { apoEL4/AB (ND) } \\
\text { (Dose dependent } \uparrow \text { complex with } \uparrow \text { ratio AB:apoE3 or apoE2) }\end{array}$ \\
\hline $\begin{array}{l}\text { Russo et al, } \\
1998[46]\end{array}$ & Human plasma apoE ${ }^{\#}$ & $\begin{array}{l}\text { Syn. } A \beta 42, \\
\text { Human } A \beta \\
\text { (Brain) }\end{array}$ & $\stackrel{*}{*}(17.7 \mathrm{pmol}: 100 \mu \mathrm{M})$ & IP with SDS-PAGE WB & apoE/Aß complex at $40 \mathrm{kDa}$ \\
\hline $\begin{array}{l}\text { Pillot et al, } \\
1999[47]\end{array}$ & Recombinant ${ }^{\#}$ & Syn. $A \beta 29-40, A \beta 29-42$ & $1: 50$ & $\begin{array}{c}\text { SDS-PAGE } \\
\text { (Non-reducing), WB }\end{array}$ & CTF-apoE/A $\beta$ > NTF-apoE/A $\beta$ (ND) \\
\hline $\begin{array}{c}\text { Yamauchi et al, } \\
1999[48]\end{array}$ & $\begin{array}{c}\text { Recombinant }{ }^{\#} \\
\text { (Non-lipidated \& lipidated) }\end{array}$ & Syn. A $\beta 42$ & $1: 2-1250$ & ELISA & $\begin{array}{c}a p o E 2 / A \beta>a p o E 3 / A \beta>a p o E 4 / A \beta \\
\text { (No differences in lipidated vs. non-lipidated in apoE isoform) }\end{array}$ \\
\hline $\begin{array}{c}\text { Aleshkov et al, } \\
1999 \text { [49] }\end{array}$ & BHK1 (CM) & Syn. Aß40 & 1:125 & $\begin{array}{c}\text { SDS-PAGE } \\
\text { (Non-reducing), WB }\end{array}$ & $\begin{array}{c}\text { apoE2/A } \beta=\text { apoE2-Thr194-Ala/A } \beta= \\
\text { apoE4-Arg158-cys/A } \beta\end{array}$ \\
\hline $\begin{array}{l}\text { Golabek et al, } \\
2000 \text { [50] }\end{array}$ & $\begin{array}{l}\text { Recombinant }{ }^{\#} \\
\text { Human plasma } \\
\text { (Purified) }\end{array}$ & Syn. A $\beta 40$ & $1: 8.5$ & $\begin{array}{c}\text { SDS-PAGE } \\
\text { (Non-reducing), WB }\end{array}$ & 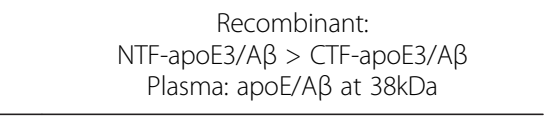 \\
\hline $\begin{array}{l}\text { Tokuda et al, } \\
2000[51]\end{array}$ & $\begin{array}{l}\text { RAW264 \& HEK293 } \\
\text { (CM, delipidated), } \\
\text { Sf9 insect cells } \\
\text { (Delipidated \& lipidated) }\end{array}$ & $\begin{array}{l}\text { Syn. } A \beta 40, \\
A \beta 42\end{array}$ & $\stackrel{*}{*}(0-150 \mathrm{nM} / 2.5 \mathrm{pmol})$ & ELISA & 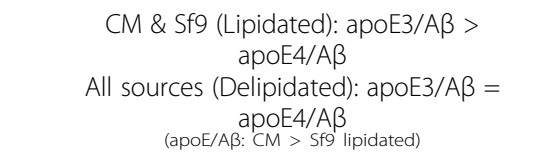 \\
\hline $\begin{array}{l}\text { Drouet et al, } \\
2001[52]\end{array}$ & Ecoli (Purified) & Syn. Aß29-40 & 1:100 & $\begin{array}{c}\text { SDS-PAGE } \\
\text { (Non-reducing), WB }\end{array}$ & 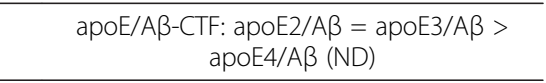 \\
\hline $\begin{array}{l}\text { Zhou et al, } \\
2002[53]\end{array}$ & $\begin{array}{c}\text { RAW264 (CM), } \\
\text { CSF (NAD E3/3, PAD E3/4, } \\
\text { AD E4/4) }\end{array}$ & Syn. A $\beta 40$ & 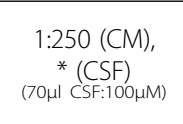 & $\begin{array}{l}\text { Co-IP, SDS-PAGE } \\
\text { (Non-reducing), WB }\end{array}$ & $\begin{array}{c}\text { CM: apoE3/A } \beta>>\text { apoE4/A } \beta \\
\text { CSF: } A P O E 33 / A \beta>A P O E 34 / A \beta= \\
A P O E 44 / A \beta \text { (ND) } \\
\text { (With BMEless apoE3/AB) }\end{array}$ \\
\hline
\end{tabular}


Table 1 Effect of apoE isoform on soluble in-vitro apoE/A $\beta$ complex levels (Continued)

\begin{tabular}{|c|c|c|c|c|c|}
\hline $\begin{array}{l}\text { Bentley et al, } \\
2002[54]\end{array}$ & HEK293 (CM) & Syn. Aß40 & 1:340 & $\begin{array}{c}\text { SDS-PAGE } \\
\text { (Non-reducing), WB }\end{array}$ & $\begin{array}{c}\text { apoE3/A } \beta>\text { apoE4/A } \beta= \\
\text { apoE3-Ala-112/A } \beta=\text { apoE4-Lys-112/A } \beta \\
(\text { ApoE3-Thr-61/A } \beta=\text { apoE4-Thr-61/A }=\text { no complex) }\end{array}$ \\
\hline $\begin{array}{l}\text { Gylys KH et al, } \\
2003[55]\end{array}$ & $\begin{array}{l}\text { Recombinant }{ }^{\#} \\
\text { (Lipidated) }\end{array}$ & Syn. Aß40 & $1: 5.6$ & $\begin{array}{c}\text { SDS-PAGE } \\
\text { (Non-reducing), WB }\end{array}$ & apoE3/sA $\beta>$ apoE3/agg $A \beta$ \\
\hline $\begin{array}{l}\text { Manelli et al, } \\
2004 \text { [56] }\end{array}$ & HEK293 (CM) & Syn. Aß42 & 1:33 & $\begin{array}{c}\text { SDS-PAGE } \\
\text { (Non-reducing), WB }\end{array}$ & $\begin{array}{c}\text { apoE3/oA } \beta>\text { apoE3/A } \beta \text { fibrils > } \\
\text { apoE4/oA }>\text { > apoE4/A } \beta \text { fibrils }\end{array}$ \\
\hline $\begin{array}{l}\text { Phu et al, } \\
2005[57]\end{array}$ & Recombinant ${ }^{\#}$ & $\begin{array}{c}\text { Syn. } \\
\text { AEDANS- } \\
\text { F4C- AB42 }\end{array}$ & $1: 1$ & FRET & Soluble complex: CTF-apoE/Aß \\
\hline $\begin{array}{l}\text { Stratman et al, } \\
2005[58]\end{array}$ & $\begin{array}{l}\text { Recombinant }{ }^{\#} \\
\text { (Lipidated) }\end{array}$ & Syn. Aß40 & $1: 500$ & ELISA & $\begin{array}{c}\text { Intermediate agg } A \beta 40: \\
\text { apoE } 4 / A \beta>>\text { apoE } 2 / A \beta=\text { apoE3/A } \beta\end{array}$ \\
\hline $\begin{array}{l}\text { Morikawa et al, } \\
2005[59]\end{array}$ & $\begin{array}{l}\text { Immortalized astrocytes } \\
\text { apoE-TR (CM immuno-purified), } \\
\text { Primary astrocytes GFAP-apoE-Tg } \\
\text { (CM Immuno-purified) }\end{array}$ & Syn. Aß40 & $1: 4.5-22.5$ & $\begin{array}{c}\text { SDS-PAGE } \\
\text { (Reducing \& } \\
\text { non-reducing), } \\
\text { WB } \\
\text { (Physiological buffer in } \\
\text { non - reducing) }\end{array}$ & $\begin{array}{l}\text { Reducing: apoE3/A } \beta>\text { apoE } 4 / A \beta \\
\text { Non-reducing: apoE3/A } \beta=\text { apoE4/A }\end{array}$ \\
\hline $\begin{array}{l}\text { Wellnitz et al, } \\
2005 \text { [60] }\end{array}$ & N2a (CM) & Syn. Aß42 & $1: 0.1-1000$ & $\begin{array}{c}\text { SDS-PAGE } \\
\text { (Reducing), WB }\end{array}$ & 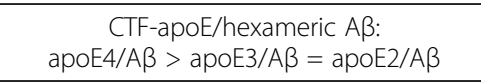 \\
\hline $\begin{array}{l}\text { Petrlova et al, } \\
2011 \text { [61] }\end{array}$ & Ecoli (Purified \& lipidated) & Syn. Aß40 & $1: 3.3$ & EPR spectroscopy & 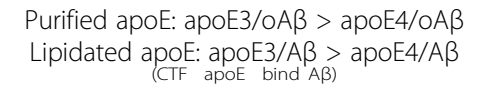 \\
\hline $\begin{array}{l}\text { Cerf et al, } \\
2011[62]\end{array}$ & Ecoli (Purified) & Syn. Aß42 & $1: 25-100$ & $\begin{array}{c}\text { SDS-PAGE } \\
\text { (Non-reducing), WB }\end{array}$ & 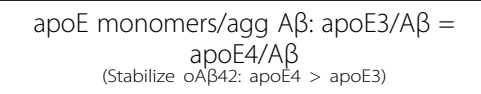 \\
\hline $\begin{array}{l}\text { Hashimoto et al, } \\
2012 \text { [27] }\end{array}$ & $\begin{array}{l}\text { Immortalized astrocytes } \\
\text { apoE-TR (CM immuno-purified) }\end{array}$ & Syn. Aß42 & $1: 0.083$ & $\begin{array}{l}\text { SDS-PAGE } \\
\text { (Reducing), WB }\end{array}$ & $\begin{array}{c}\text { No complex measured } \\
\text { Lipidated apoE stabilizes oAß42: apoE4 > } \\
\text { apoE3 }>\text { apoE2 }\end{array}$ \\
\hline $\begin{array}{l}\text { LaDu et al, } \\
2012 \text { [63] }\end{array}$ & $\begin{array}{c}\text { Human Plasma (NAD), } \\
\text { Rat Astrocyte } \\
\text { (CM, isolated, purified delipidated) }\end{array}$ & Syn. Aß40 & $\begin{array}{c}\text { 1:5-16 (Plasma); } \\
\text { 1:36 } \\
\text { (Rat ACM); 1:357 } \\
\text { (Rat isolated \& purified) }\end{array}$ & $\begin{array}{c}\text { SEC, SDS-PAGE } \\
\text { (Non-reducing), WB }\end{array}$ & $\begin{array}{c}\text { A } \beta \text { co-elutes with apoE containing } \\
\text { lipoproteins: Human plasma }(70 \%)> \\
\text { rat } A C M(53 \%) \\
\text { Monomer apoE/Aß }(45 \mathrm{kDa}) \& \text { dimer } \\
\text { apoE/Aß 97kDa : rat isolated }>\text { rat purified }\end{array}$ \\
\hline $\begin{array}{l}\text { Ly et al, } \\
2013[64]\end{array}$ & Ecoli (Purified) & Syn. Aß40 & $1-4: 1,1: 2$ & $\begin{array}{l}\text { Laser fluorescence } \\
\text { spectroscopy }\end{array}$ & $\begin{array}{c}\text { Stable complex- apoE3L-Cys-264/oA }> \\
\text { apoE4-Cys-264/oA } \\
\text { (apoE3L means "apoE3 like" with Cys1 12-Ser) }\end{array}$ \\
\hline
\end{tabular}


Table 1 Effect of apoE isoform on soluble in-vitro apoE/A $\beta$ complex levels (Continued)

\begin{tabular}{|c|c|c|c|c|c|}
\hline $\begin{array}{l}\text { Tai et al, } \\
2013[4]\end{array}$ & HEK293 (CM) & Syn. A $\beta 42$ & $1: 0.005-50$ & ELISA & 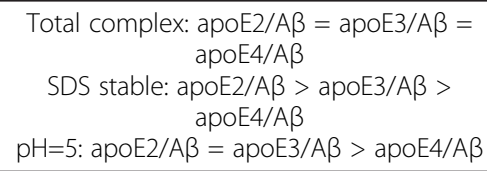 \\
\hline \multirow{3}{*}{$\begin{array}{l}\text { Verghese et al, } \\
2013[65]\end{array}$} & $\begin{array}{l}\text { Recombinant } \\
\quad \text { (Lipidated) }\end{array}$ & $\begin{array}{c}\text { APP H4 } \\
\text { neuroglioma } \\
\text { (CM), Syn. A } 340 / 42\end{array}$ & $\begin{array}{l}\text { 1:0.02-0.05 (CM), } \\
\text { 1:0.2-1 (Syn.) }\end{array}$ & $\begin{array}{c}\text { Density gradient } \\
\text { ultracentrifugation, } \\
\text { SEC, ELISA, FCS (Reducing) }\end{array}$ & $\begin{array}{c}\text { Monomeric } A \beta \text { free }(95-97 \%)>> \\
\text { apoE3/A } A=\text { apoE4/A } A \beta \\
\text { (Lipidated apoE poorly binds binds } A \beta \text { ) }\end{array}$ \\
\hline & $\begin{array}{l}\text { Immortalized astrocytes } \\
\text { apoE-TR } \\
\text { (CM immuno-purified), } \\
\text { Primary astrocytes } \\
\text { GFAP-apoE-Tg } \\
\text { (CM Immuno-purified) }\end{array}$ & $\begin{array}{c}\text { APP H4 } \\
\text { neuroglioma (CM), } \\
\text { 7PA2 cells (CM) }\end{array}$ & $\begin{array}{l}\text { 1:0.04 }(\mathrm{H} 4), 1: 0.05 \\
\quad(7 P A 2)\end{array}$ & SEC, ELISA, FCS (Reducing) & $\begin{array}{c}\text { Higher order } A \beta \text { species (free) }>> \\
\text { apoE3/A } A=\text { apoE } 4 / A \beta\end{array}$ \\
\hline & $\begin{array}{c}\text { Human CSF (Pooled } \\
\text { non-concentrated, NAD) }\end{array}$ & $\begin{array}{l}\text { APP H4 } \\
\text { neuroglioma } \\
\text { (CM) }\end{array}$ & $\begin{array}{c}* \\
(800 \mu l \\
\text { CSF:50ng/ml) }\end{array}$ & SEC & $\begin{array}{l}95 \% \text { in vitro } A \beta \text { (free) }= \\
\text { in vivo } A \beta \text { (free) }>>\text { apoE/A }\end{array}$ \\
\hline
\end{tabular}

\#, Commercially purchased recombinant human apoE; *, apoE:A $\beta$ ratio unknown; Lipidated apoE is either with POPC, reconstituted "HDL" or plasma lipoprotein.

ACM, Astrocyte conditioned media; AD, Alzheimer's disease; agg A $\beta$, Aggregated A $\beta$; BME, $\beta$ - mercaptoethanol; CSF, Cerebrospinal fluid; CM, Conditioned media; co-IP, co - immunoprecipitation; CTF, C-terminal

fragment; EPR, Electron paramagnetic resonance; ELISA, Enzyme-linked immunosorbent assay; FCS, Fluorescence correlation spectroscopy; FRET, Fluorescence resonance energy transfer; IP, Immunoprecipitation; NAD,

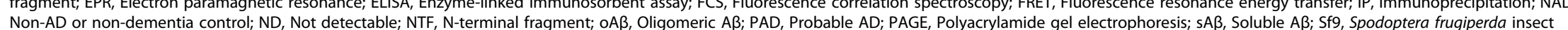

cells; SDS, Sodium dodecyl sulfate; SEC, Size exclusion chromatography; Syn, Synthetic; Tg, Transgenic; TR, Target replacement; WB, western blot. 
Table 2 Effect of apoE isoform on soluble in-vivo apoE/A $\beta$ complex levels

\begin{tabular}{|c|c|c|c|}
\hline Study & Biological source & Detection method & Results \\
\hline Naslund et al, 1995 [36] & Human brain (AD \& NAD) & SDS-PAGE & $A D>N A D$, No apoE isoform differences measured \\
\hline \multirow[t]{3}{*}{ Russo et al, 1998 [46] } & Human brain (AD \& NAD) & IP, SDS-PAGE WB & NAD apoE23/A $\beta=N A D$ apoE33/A $\beta=N A D$ apoE34/A $\beta>>$ \\
\hline & & & $A D$ apoE33/A $>$ AD apoE44/A \\
\hline & & & SDS \& protease digestion stability: NAD > AD \\
\hline Yamauchi et al, 1999 [48] & Human CSF \& serum (NAD) & SDS-PAGE (Non-reducing), WB & apoE33/Aß > apoE44/Aß (ND) \\
\hline Hashimoto et al, 2012 [27] & Human brain (NAD) & SEC, SDS-PAGE (Reducing), WB & No complex measured, HMW A $\beta$ interacts with apoE on HDL particles \\
\hline \multirow[t]{2}{*}{ LaDu et al, 2012 [63] } & Human plasma (NAD) & SEC, SDS-PAGE (Non-reducing), WB & 95\% A $\beta$ elutes with lipoproteins \\
\hline & Human CSF (NAD) & & 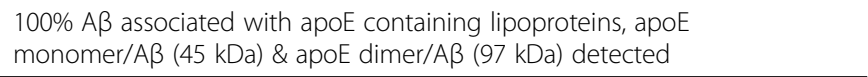 \\
\hline \multirow[t]{7}{*}{ Tai et al, 2013 [4] } & Hippocampal homogenates (EFAD mice) & ELISA & SDS stable: E2FAD > E3FAD > E4FAD Total complex: E2FAD = E3FAD > E4FAD \\
\hline & Human cortical synaptosomes (AD \& NAD) & & Total complex: \\
\hline & & & $\cdot N A D>A D$ \\
\hline & & & - NAD apoE33/AB = NAD apoE4X/AB >> AD apoE33/AB > AD apoE4X/AB \\
\hline & & & SDS stable: \\
\hline & & & - NAD apoE33/AB > > NAD apoE4X/AB \\
\hline & Human CSF (AD \& NAD) & & $N A D>A D, N A D$ apoE33/A $\beta>A D$ apoE33/A $>$ > AD apoE44/A $\beta$ \\
\hline \multirow[t]{2}{*}{ Verghese, et al, 2013 [65] } & Human CSF (NAD) & SEC, ELISA & $95 \% A \beta$ (free) $>>$ apoE $33 / A \beta=$ apoE $44 / A \beta$ \\
\hline & & & $\begin{array}{l}\text { No apoE isoform differences } \\
\text { (In co-elution peak stoichiometric ratio of apoE:A } \beta=1: 0.0002-0.0003)\end{array}$ \\
\hline
\end{tabular}

AD, Alzheimer's disease patients; CSF, Cerebrospinal fluid; ELISA, Enzyme-linked immunosorbent assay; HDL, High density lipoprotein; HMW, High molecular weight; IP, Immuno-precipitation; NAD, Non-AD or non-dementia control; ND, Not detected; PAGE, Polyacrylamide gel electrophoresis; SDS, Sodium dodecyl sulfate; SEC, Size exclusion chromatography; WB, Western blot. 
apoE3 $[30,66]$. However, this affinity is reversed using lipidated apoE; levels of apoE3/A $\beta$ complex are significantly greater than apoE4/A $\beta$ complex $[30,33,66]$.

\section{Interpretation}

Landmark studies are consistent with the decreased stability of in-vitro apoE4/A $\beta$ complex compared to the apoE3/A $\beta$ when a "physiological relevant" source of apoE is used. Further, the presence of both detergent and a reducing agent significantly reduce complex levels, with apoE4/A $\beta$ affected more than apoE3/A $\beta$. Importantly, soluble levels of in-vivo apoE/A $\beta$ complex levels are lower and the complex less stable in AD versus NAD brain samples, suggesting a link between apoE isoformspecific formation of apoE/A $\beta$ complex and $A D$, for which $A P O E 4$ is the greatest risk factor.

\section{Recent data}

\section{Is there a soluble apoE/A $\beta$ complex?}

A recent publication by Verghese and co-workers brought into question the significance of the apoE/A $\beta$ complex for modulating $A \beta$ levels [65]. Although the overall goal of the study was to determine the effect of apoE/A $\beta$ complex on $A \beta$ metabolism, the authors noted that apoE forms minimal complex with $A \beta$ [65]. For in-vitro apoE/A $\beta$ complex, only $5 \%$ of cell-derived $A \beta$ formed a complex with apoE (astrocyte derived or lipid reconstituted) when analyzed using gradient ultracentrifugation, SEC followed by ELISA analysis and fluorescence correlation spectroscopy (FCS) [65]. The apparent difference between these results and previous studies, where cell-derived apoE and $\mathrm{A} \beta$ formed a significant amount of apoE/A $\beta$ complex, was attributed to a non-physiologically high ratio of $A \beta$ to apoE. Indeed, previous studies often added $A \beta$ in excess of apoE (Table 1), whereas Verghese and co-workers used "physiological" ratios of apoE to $A \beta$ [65]. However, in CSF, plasma and brain homogenates from humans and FAD$\mathrm{Tg}$ mice, the concentrations of $\mathrm{A} \beta$ are significantly lower than apoE. For example, the apoE: $\mathrm{A} \beta$ ratios reported for human CSF are in the range of 1:0.006-0.02 [72-74]. In addition, density gradient centrifugation is known to induce loss of (apolipo)proteins from lipoproteins [67], which would likely effect the components of the apoE/A $\beta$ complex isolated by this method. Finally, FCS analysis requires $\beta$-ME, which disrupts apoE/A $\beta$ complex [42].

Verghese and co-workers report similar results for invivo apoE/A $\beta$ complex in human CSF, with only 5\% of apoE and $A \beta$ co-eluting from SEC in fractions analyzed by ELISA [65]. This is in contrast to a previous study that demonstrated $\sim 100 \%$ co-elution of apoE and $\mathrm{A} \beta$ from human CSF [63]. Although no data are presented, the hypothesis is that concentration of the CSF 10-30-fold prior to SEC as used in the previous publications [63,75], may have induced apoE/A $\beta$ complex formation.

APOE modulates soluble apoE/A $\beta$ levels measured by ELISA To determine the effect of apoE isoform on apoE/A $\beta$ complex levels under non-stringent conditions, we developed an apoE/A $\beta$ complex ELISA to detect both the total levels of apoE/A $\beta$ complex and, after the addition of SDS, the stability of the apoE/A $\beta$ complex [4]. With this technique, using cell-derived apoE and synthetic A $\beta 42$ at physiological ratios (in-vitro complex), total apoE/A $\beta$ complex levels were equivalent for the three apoE isoforms, whereas SDS-stability of the apoE/A $\beta$ complex was isoform-specific; apoE2/A $\beta>$ apoE3/A $\beta>$ apoE4/A $\beta$, consistent with previous results utilizing alternative, non-stringent detection methods [33,41,42,54]. In addition, using this ELISA, the apoE/A $\beta$ complex is less stable at a low $\mathrm{pH}[4]$, also in agreement with previous data [66].

With the apoE/A $\beta$ complex ELISA, we also identified an $A P O E$ genotype-specific difference in in-vivo apoE/ $\mathrm{A} \beta$ complex levels in EFAD-Tg mice and human samples [4]. In EFAD-Tg mice, soluble levels of apoE4/A $\beta$ complex were lower and less stable compared to apoE3/A $\beta$ and apoE2/A $\beta$. Further, soluble oA $\beta$ levels were higher in E4FAD mice compared to E2FAD and E3FAD mice, suggesting that apoE/A $\beta$ complex may modulate oA $\beta$ levels. In human synaptosome preparations and CSF, apoE/A $\beta$ levels were lower in AD compared to NAD samples, and with APOE4 compared to APOE3 in the AD cohort. Importantly, in human CSF, oA $\beta$ increased and was greater with $A P O E 4$ in the $\mathrm{AD}$ cohort, in contrast to total $\mathrm{A} \beta 42$ levels that decrease with AD compared to NAD, with levels at the limit of detection in the $\mathrm{AD}$ cohort with both $A P O E 3$ and $A P O E 4$. Taken together, the low levels of soluble apoE4/A $\beta$ complex and high levels of soluble oA $\beta$ suggest a potential basis for APOE4-induced $\mathrm{AD}$ risk.

\section{Interpretation}

As we seek to define the role of apoE/A $\beta$ complex in the parenchyma of the brain, extracting intact lipoproteins from tissue homogenates is critically important but procedurally problematic. For now, the optimal CNS samples are soluble brain homogenates or CSF. In addition, as discussed in the previous section, multiple factors are known to influence the detection of apoE/ $\mathrm{A} \beta$ complex levels. One technique is not necessarily superior to another; each has merits and limitations. Thus, future studies may utilize multiple, complementary techniques for sample analysis. Overall, based on the literature and our recent data demonstrating an inverse relationship between the levels of soluble apoE/A $\beta$ complex and oA $\beta$, we hypothesize that complex plays a 
significant role in modulating oA $\beta$ levels. The lower levels and instability of apoE4/A $\beta$ complex compared to apoE3/A $\beta$ suggests a potential mechanism for the APOE4-induced risk for AD.

\section{Does apoE isoform-specific lipoprotein lipidation affect apoE/A $\beta$ complex levels?}

$\mathrm{CNS}$ apolipoproteins are exclusively produced within the brain and apoE is the major apolipoprotein in the CNS [70]. The biogenesis of CNS apolipoproteins occurs primarily in the interstitial fluid and a proposed model of lipoprotein remodeling includes: 1) glial cells secrete nascent apoE-containing lipoproteins that are lipid-poor and discoidal in shape; 2) ABCA1 and ABCG1 in glia and neurons efflux free cholesterol to these lipoproteins, increasing the lipidation state of this now intermediate lipoprotein particle; and 3) intermediate particles mature and likely become spherical through acquiring a cholesteryl ester core and additional phospholipids [76]. Thus, apoE isoform-specific lipoprotein lipidation is a critical parameter that modulates the overall function of these lipoproteins, including the formation of apoE/A $\beta$ complex.

\section{ApoE modulation of lipoprotein lipidation}

The general dogma in the field is that apoE4 in the CNS is less lipidated than apoE3. However, it is difficult to isolate and analyze intact CNS lipoproteins, thus limiting direct study of the lipidation state of apoE4-particles versus apoE3-particles. However, the functional consequences of conditions predicted to affect the lipidation state of lipoproteins have provided valuable insights. For example, in vitro data demonstrate that glia-mediated degradation of apoE is increased and cholesterol release is reduced in primary glial cultures expressing apoE4 compared to apoE3 [77,78]. In vivo study of Tg mice using over-expression or knock-out of the $\mathrm{ABC}$ transporters has also provided important information on the functional effects of the lipidation state of CNS lipoproteins [79-82]. For example, Fitz and co-workers demonstrated that introducing $\mathrm{ABCA1}^{-/+}$to an $\mathrm{FAD} / \mathrm{apoE}-\mathrm{Tg}$ mouse results in increased plaque deposition and a general AD phenotype in mice expressing apoE4 but not apoE3 [82]. In addition, we recently developed a three-step sequential protein extraction protocol (TBS, TBSX, formic acid/FA). A non-ionic detergent Triton X-100 (TBSX) is used to in an attempt to release apoE from lipoprotein particles without inducing the formation of new micelles, as can occur with ionic detergents such as SDS [12,83]. Using EFAD mouse brain extraction fractions, we demonstrated that while total brain apoE4 levels are lower compared to apoE2 and apoE3, this decrease is seen only in the TBSX fraction [12]. These data provide evidence that less apoE4 is associated with lipoproteins and thus apoE4 may be less lipidated than apoE2 and apoE3.

\section{ApoE lipoprotein lipidation and apoE/A $\beta$ complex levels}

Biophysical data demonstrates that, compared to apoE3, apoE4 has an increased propensity to populate an intermediate molten globule state during denaturation, suggesting a less stable conformation [84-86]. Thus, the decreased stability of apoE4-containing lipoproteins may, in part, explain the decreased stability of the apoE4/A $\beta$ complex compared to the apoE3/A $\beta$ complex. An additional consideration is whether apoE and $A \beta$ form a direct complex, or whether $A \beta$ interacts with the lipid surface of apoE-containing lipoproteins, which likely comprise a relatively larger surface area of the lipoprotein particle compared to apoE. Simplistically, if apoE4-containing lipoproteins are less lipidated than apoE3-containing lipoproteins, then a smaller surface area is provided on a less stable lipoprotein for interactions with $A \beta$.

\section{Interpretation}

Identifying whether apoE4-containing lipoproteins are less lipidated than apoE3- containing lipoproteins, and which lipids differ between the two, are important considerations. If, as hypothesized, apoE4-containing lipoproteins are less lipidated than apoE3 containing lipoproteins, this may explain the reduced levels and stability of the apoE4/A $\beta$ complex.

\section{How might apoE/A $\beta$ complex modulate soluble $A \beta$ levels?}

The functional key question in this field is how apoE/A $\beta$ complex modulates soluble $A \beta$ levels. Although there are a number of proposed mechanisms, they generally fall into 2 categories: 1 ) modulation of $A \beta$ clearance, and 2) $\mathrm{A} \beta$ aggregation.

\section{$\mathrm{A} \beta$ clearance}

The $A \beta$ clearance rate is slower with apoE4 compared to apoE3 in PDAPP/apoE-TR mice [87] and in apoE-TR mice after a bolus brain injection of $A \beta$ [88]. ApoE exhibits an isoform-specific effect on a number of cellular processes that modulate soluble $A \beta$ clearance, and the mechanisms underlying these effects may be influenced by apoE/A $\beta$ complex levels. Compared to apoE3, apoE4 results in a decrease in $A \beta$ levels via: 1$)$ clearance via glia [89-93], neurons [94-96], and the blood-brain barrier [88,97]; 2) intracellular and parenchymal enzymatic degradation [93]; and 3) drainage via the interstitial fluid (ISF) [87] and perivasculature [98]. One potential mechanism is that soluble apoE3/A $\beta$ complex may reduce soluble $A \beta$ levels via clearance, whereas the lower levels of soluble apoE4/A $\beta$ complex result in higher soluble $A \beta$ levels, particularly oA $\beta$. In terms of cellular clearance, the literature appears contradictory, likely due to the variety of models and reagents used, including; glia versus neurons, mouse versus human cells, mouse versus 
human apoE, source of apoE (purified protein or lipidated particle), source and aggregation state of the $A \beta$, etc. In a particularly relevant study, Nielson and co-workers used primary human astrocytes to address the role of the human apoE isoforms in binding and uptake of $\mathrm{A} \beta 42$. Their results demonstrated that both apoE3 and apoE4 inhibited the uptake of oA $\beta 42$ but not fibrillar forms of the peptide [99].

\section{$A \beta$ aggregation}

Data are conflicting as to the effect of apoE/A $\beta$ complex on $A \beta$ aggregation. Previous publications have demonstrated that apoE promotes $A \beta$ aggregation, resulting in retention of the peptide; within glia [99], as intraneuronal $A \beta$ [100], or in the parenchyma as either diffuse $A \beta$ deposits or amyloid [12]. APOE4 is associated with an increase in amyloid deposition, suggesting that apoE functions as a "pathological chaperone", an effect that might actually be beneficial [101]. However, as demonstrated in vitro, apoE isolated from human brain increases the oligomerization of $\mathrm{A} \beta$ [27], an effect that is greater with apoE4 compared to apoE3. This is consistent with the hypothesis that apoE binds to oA $\beta$ and prevents further aggregation [64]. These results would favor the view that lower levels of apoE/A $\beta$ complex are beneficial $[102,103]$.

\section{Interpretation}

Delineating the effect of apoE/A $\beta$ complex on $A \beta$ clearance and aggregation is complex due to the multiple mechanisms involved in these processes. It is particularly difficult to interpret in vitro data as the studies focus on multiple, different intercellular and intracellular pathways. At this point, research appears to support a role for apoE/ $A \beta$ complex in both promoting $A \beta$ clearance and $A \beta$ aggregation, both as insoluble amyloid and soluble oA $\beta$.

\section{How can the apoE/A $\beta$ complex be targeted therapeutically?}

Therapeutics that target the apoE/A $\beta$ complex can be broadly divided in those that increase the ability of apoEcontaining lipoproteins to form an apoE/A $\beta$ complex and those that disrupt apoE/A $\beta$ complex.

\section{Therapies to increase apoE/A $\beta$ complex Nuclear receptor agonists}

Increasing the lipidation of apoE-containing lipoproteins may increase apoE/A $\beta$ complex levels and decrease oA $\beta$ levels. As described above, the transporters ABCA1 and ABCG1 expressed by glia and neurons in the CNS are considered the major transporters of lipid to the nascent CNS apoE-containing lipoproteins [76]. Agonists for the nuclear receptors PPARY [104-106], LXR (reviewed in [107]) and RXR [108-111] increase ABCA1 and ABCG1 expression and decrease soluble $A \beta$ levels in FAD-Tg mice. However, controversy exists over the activity and mechanism of action of these agents, highlighted by recent data with the RXR agonist bexarotene [112]. Initial data demonstrated that bexarotene increased apoE levels and decreased soluble $A \beta$ within hours and significantly reduced insoluble $A \beta$ after three days [112]. These data were purported to be consistent with an apoE-induced increase clearance of both soluble and insoluble $A \beta$. However, very recent findings indicate that bexarotene treatment of FAD-Tg mice reduced soluble $A \beta$ and improved memory without changing amyloid or apoE levels but with increased ABCA1 expression [108-111]. Therefore, a potential novel mechanism of action of RXR agonists is an increase in ABCA1 expression, which results in increased lipid content/lipidation of apoE-containing lipoproteins, a process that may be particularly beneficial to lipid-poor apoE4-containing lipoproteins. This increased lipidation likely results in an increase in apoE/A $\beta$ complex levels and a decrease in soluble $A \beta 42$ levels, as discussed in Section 4 above.

\section{Dietary strategies}

A recent publication highlighted the effect of $A P O E$ and diet on $A \beta$ levels and apoE lipidation in patients with MCI [113]. The overall conclusion was that with a high saturated fat or glycemic diet, apoE was less lipidated and it formed lower levels of apoE/A $\beta$ complex, resulting in reduced $A \beta$ clearance and increased $A \beta$ oligomerization and toxicity [113]. Thus, dietary interventions may prove effective for raising apoE/A $\beta$ complex levels.

\section{Therapies to block apoE/A $\beta$ complex Aß12-28P}

The potential for apoE to increase $A \beta$ aggregation, and even specifically oligomerization, led to the development of the $A \beta 12-28 \mathrm{P}$, an $A \beta$ peptide purported to block the formation of apoE/A $\beta$ complex $[102,103]$. In vivo data demonstrate that $A \beta 12-28$ P lowers insoluble $A \beta$ both in the brain $[102,103]$ and vasculature [114] of FAD-Tg mice. However, data on the effect of this peptide on apoE/A $\beta$ complex levels are limited. In addition, A $\beta 12-28 \mathrm{P}$ has not been tested in the absence of apoE (apoE-KO mice), leaving open the possibility that it may be interacting directly with $A \beta$ to reduce aggregation. Therefore, the mechanism of action of $\mathrm{A} \beta 12-28 \mathrm{P}$ in vivo is currently unclear.

\section{Interpretation}

A major hurdle to interpreting how therapeutic or dietary interventions modulate apoE/A $\beta$ complex, $\mathrm{A} \beta$ accumulation, and ultimately $\mathrm{AD}$, is their pleiotropic mechanisms of action. For example, LRX/RXR/PPAR $\gamma$ agonists display anti-inflammatory actions, which may or may not be dependent on lipoprotein lipidation, and ABCA1 may directly clear $A \beta$. However, data with nuclear receptor 
agonists suggests that increasing ABCA1/ABCG1 expression will increase lipoprotein lipidation, apoE/A $\beta$ complex levels and $A \beta$ clearance, thus reducing soluble oA $\beta$ levels.

\section{Conclusions}

Our hypothesis is that the APOE4-induced risk of AD is consistent with the following pathway to neurodegeneration: Compared to apoE3, apoE4-containing lipoproteins are less lipidated, which reduces stability, resulting in lower levels the apoE4/A $\beta$ complex. Reduced levels of apoE4/A $\beta$ complex result in increased $A \beta$ accumulation, specifically oA $\beta$ levels. Thus, increasing the lipidation of apoE-containing lipoproteins may reduce $A \beta$ accumulation, an effect particularly effective with the lipid-poor apoE4-lipoproteins.

\section{Abbreviations}

ABC: ATP-binding cassette transporter; A $\beta$ : Amyloid- $\beta$; AD: Alzheimer's disease; apoE: Apolipoprotein E; apoE-TR: ApoE targeted replacement mice; $\beta$-ME: $\beta$-mercaptoethanol; CNS: Central nervous system; CSF: Cerebrospinal fluid; DB: Dot blot; DTT: Dithiothreitol; EFAD mice: $5 \times$ FAD mice crossed with apoE-TR mice; FAD: Familial Alzheimer's disease; FAD-Tg: Transgenic mice expressing APP and/or PS1 with FAD mutations; FCS: Fluorescence correlation spectroscopy; IHC: Immunohistochemistry; IP: Immunoprecipitation; ISF: Interstitial fluid; NAD: Non-AD; OAß42: Oligomeric AB; SDS-PAGE: Sodium dodecyl sulphate polyacrylamide gel electrophoresis; Tg: Transgenic: WB: Western blot; 5xFAD: Mice containing 5 FAD mutations.

\section{Competing interests}

In collaboration with Skip Binder, MJL developed the antibody MOAB-2 used to develop the apoE/AB complex and OAB ELISAs. MOAB-2 is licensed as a research tool to multiple companies. Also for research purposes, Biosensis Pty $L$ td has licensed the rights to ELISA kits with MOAB-2 for OA $\beta$ and apoE/A $\beta$.

\section{Authors' contributions}

LMT: Prepared the manuscript and Tables. SM: Provided input on, and preparation of, the Tables with LMT and MJL. VS: Provided significant input on final manuscript preparation, revision and submission. SE/GWR/GB: Collaborators who advised and provided significant input on the content and direction of the manuscript text. MJL: Provided fundamental contributions to the manuscript conception and preparation. All authors read and approved the final manuscript.

\section{Acknowledgements}

This work was supported, in whole or in part, by NIH/NIA P01AG030128, Alzheimer's Association Grant ZEN-08-899000, University of Illinois at Chicago Center for Clinical and Translational Science Grant UL1RR029879 and Alzheimer's Drug Discovery Foundation Grant to MJL.

MJL would like to acknowledge Skip Binder for his 20+ years of contributions to her study of $A \beta$, albeit "an irrelevant peptide". His opinions will be sorely missed.

\section{Author details}

'Department of Anatomy and Cell Biology, University of Illinois at Chicago, 808 S. Wood St., M/C 512, Chicago, IL 60612, USA. ${ }^{2}$ Sanders-Brown Center on Aging, University of Kentucky, Lexington, KY 40536, USA. ${ }^{3}$ Department of Neuroscience, Georgetown University, Washington, DC 20057, USA. ${ }^{4}$ Department of Neuroscience, Mayo Clinic, Jacksonville, FL 32224, USA.

Received: 28 November 2013 Accepted: 27 December 2013 Published: 4 January 2014

\section{References}

1. Reitz C, Mayeux R: Use of genetic variation as biomarkers for mild cognitive impairment and progression of mild cognitive impairment to dementia. J Alzheimers Dis 2010, 19:229-251.
2. Leoni $\mathrm{V}$ : The effect of apolipoprotein $\mathrm{E}$ (ApoE) genotype on biomarkers of amyloidogenesis, tau pathology and neurodegeneration in Alzheimer's disease. Clin Chem Lab Med 2011, 49:375-383.

3. Liu CC, Kanekiyo T, Xu H, Bu G: Apolipoprotein E and Alzheimer disease: risk, mechanisms and therapy. Nat Rev Neurol 2013, 9:106-118.

4. Tai LM, Bilousova T, Jungbauer L, Roeske SK, Youmans KL, Yu C, Poon WW Cornwell LB, Miller CA, Vinters HV, et al: Levels of soluble apolipoprotein E/ amyloid-beta (Abeta) complex are reduced and oligomeric Abeta increased with APOE4 and Alzheimer disease in a transgenic mouse model and human samples. J Biol Chem 2013, 288:5914-5926.

5. Lue LF, Kuo YM, Roher AE, Brachova L, Shen Y, Sue L, Beach T, Kurth JH, Rydel RE, Rogers J: Soluble amyloid beta peptide concentration as a predictor of synaptic change in Alzheimer's disease. Am J Pathol 1999, 155:853-862.

6. McLean CA, Cherny RA, Fraser FW, Fuller SJ, Smith MJ, Beyreuther K, Bush Al, Masters CL: Soluble pool of Abeta amyloid as a determinant of severity of neurodegeneration in Alzheimer's disease. Ann Neurol 1999, 46:860-866.

7. Wang J, Dickson DW, Trojanowski JQ, Lee VM: The levels of soluble versus insoluble brain Abeta distinguish Alzheimer's disease from normal and pathologic aging. Exp Neurol 1999, 158:328-337.

8. Tomic JL, Pensalfini A, Head E, Glabe CG: Soluble fibrillar oligomer levels are elevated in Alzheimer's disease brain and correlate with cognitive dysfunction. Neurobiol Dis 2009, 35:352-358.

9. Jin M, Shepardson N, Yang T, Chen G, Walsh D, Selkoe DJ: Soluble amyloid beta-protein dimers isolated from Alzheimer cortex directly induce Tau hyperphosphorylation and neuritic degeneration. Proc Natl Acad Sci USA 2011, 108:5819-5824.

10. Kuo YM, Emmerling MR, Vigo-Pelfrey C, Kasunic TC, Kirkpatrick JB, Murdoch GH, Ball MJ, Roher AE: Water-soluble Abeta (N-40, N-42) oligomers in normal and Alzheimer disease brains. J Biol Chem 1996, 271:4077-4081.

11. Selkoe DJ: Resolving controversies on the path to Alzheimer's therapeutics. Nat Med 2011, 17:1060-1065.

12. Youmans KL, Tai LM, Nwabuisi-Heath E, Jungbauer L, Kanekiyo T, Gan M, Kim J, Eimer WA, Estus S, Rebeck GW, et al: APOE4-specific changes in Abeta accumulation in a new transgenic mouse model of Alzheimer disease. J Biol Chem 2012, 287:41774-41786.

13. Thal DR, Griffin WS, Braak H: Parenchymal and vascular Abeta-deposition and its effects on the degeneration of neurons and cognition in Alzheimer's disease. J Cell Mol Med 2008, 12:1848-1862.

14. Thal DR, Capetillo-Zarate E, Del Tredici K, Braak H: The development of amyloid beta protein deposits in the aged brain. Sci Aging Knowledge Environ 2006, 2006:re1.

15. Haass C, Selkoe DJ: Soluble protein oligomers in neurodegeneration: lessons from the Alzheimer's amyloid beta-peptide. Nat Rev Mol Cell Biol 2007, 8:101-112.

16. Klein WL: Abeta toxicity in Alzheimer's disease: globular oligomers (ADDLs) as new vaccine and drug targets. Neurochem Int 2002, 41:345-352.

17. Hong S, Quintero-Monzon O, Ostaszewski BL, Podlisny DR, Cavanaugh WT, Yang T, Holtzman DM, Cirrito JR, Selkoe DJ: Dynamic analysis of amyloid beta-protein in behaving mice reveals opposing changes in ISF versus parenchymal Abeta during age-related plaque formation. J Neurosci 2011, 31:15861-15869.

18. Hudry E, Dashkoff J, Roe AD, Takeda S, Koffie RM, Hashimoto T, Scheel M, Spires-Jones T, Arbel-Ornath M, Betensky R, et al: Gene transfer of human apoe isoforms results in differential modulation of amyloid deposition and neurotoxicity in mouse brain. Sci Trans/ Med 2013, 5:212ra161.

19. Lesne SE, Sherman MA, Grant M, Kuskowski M, Schneider JA, Bennett DA, Ashe KH: Brain amyloid-beta oligomers in ageing and Alzheimer's disease. Brain 2013, 136:1383-1398.

20. Hardy J: Alzheimer's disease: the amyloid cascade hypothesis: an update and reappraisal. J Alzheimers Dis 2006, 9:151-153.

21. Larson ME, Lesne SE: Soluble Abeta oligomer production and toxicity. J Neurochem 2012, 120(Suppl 1):125-139.

22. Kim J, Jiang H, Park S, Eltorai AE, Stewart FR, Yoon H, Basak JM, Finn MB, Holtzman DM: Haploinsufficiency of human APOE reduces amyloid deposition in a mouse model of amyloid-beta amyloidosis. J Neurosci 2011, 31:18007-18012

23. Bales KR, Liu F, Wu S, Lin S, Koger D, DeLong C, Hansen JC, Sullivan PM, Paul SM: Human APOE isoform-dependent effects on brain beta-amyloid levels in PDAPP transgenic mice. J Neurosci 2009, 29:6771-6779.

24. Drzezga A, Grimmer T, Henriksen G, Muhlau M, Perneczky R, Miederer I, Praus C, Sorg C, Wohlschlager A, Riemenschneider M, et al: Effect of APOE 
genotype on amyloid plaque load and gray matter volume in Alzheimer disease. Neurology 2009, 72:1487-1494.

25. Grimmer $T$, Tholen $S$, Yousefi BH, Alexopoulos P, Forschler A, Forstl H, Henriksen G, Klunk WE, Mathis CA, Perneczky R, et al: Progression of cerebral amyloid load is associated with the apolipoprotein E epsilon4 genotype in Alzheimer's disease. Biol Psychiatry 2010, 68:879-884.

26. Koffie RM, Hashimoto T, Tai HC, Kay KR, Serrano-Pozo A, Joyner D, Hou S, Kopeikina KJ, Frosch MP, Lee VM, et al: Apolipoprotein E4 effects in Alzheimer's disease are mediated by synaptotoxic oligomeric amyloid-beta. Brain 2012, 135:2155-2168.

27. Hashimoto T, Serrano-Pozo A, Hori Y, Adams KW, Takeda S, Banerji AO, Mitani A, Joyner D, Thyssen DH, Bacskai BJ, et al: Apolipoprotein E, especially apolipoprotein $\mathrm{E} 4$, increases the oligomerization of amyloid beta peptide. J Neurosci 2012, 32:15181-15192.

28. Sokolow S, Henkins KM, Bilousova T, Miller CA, Vinters HV, Poon W, Cole GM, Gylys KH: AD synapses contain abundant Abeta monomer and multiple soluble oligomers, including a 56-kDa assembly. Neurobiol Aging 2012, 33:1545-1555

29. Strittmatter WJ, Saunders AM, Schmechel D, Pericak-Vance M, Enghild J Salvesen GS, Roses AD: Apolipoprotein E: high-avidity binding to betaamyloid and increased frequency of type 4 allele in late-onset familia Alzheimer disease. Proc Natl Acad Sci U S A 1993, 90:1977-1981.

30. Strittmatter WJ, Weisgraber KH, Huang DY, Dong LM, Salvesen GS, Pericak-Vance M, Schmechel D, Saunders AM, Goldgaber D, Roses AD: Binding of human apolipoprotein $\mathrm{E}$ to synthetic amyloid beta peptide: isoform-specific effects and implications for late-onset Alzheimer disease. Proc Natl Acad Sci USA 1993, 90:8098-8102.

31. Wisniewski T, Golabek A, Matsubara E, Ghiso J, Frangione B: Apolipoprotein E: binding to soluble Alzheimer's beta-amyloid. Biochem Biophys Res Commun 1993, 192:359-365.

32. Sanan DA, Weisgraber KH, Russel SJ, Mahley RW, Huang D, Saunders A Schmechel D, Wisniewksi T, Frangione B, Roses B, et al: Apolipoprotein E associates with $\beta$ amyloid peptide of Alzheimer's disease to form novel monofibrils. J Clin Invest 1994, 94:860-869.

33. LaDu MJ, Falduto MT, Manelli AM, Reardon CA, Getz GS, Frail DE: Isoform-specific binding of apolipoprotein $\mathrm{E}$ to beta-amyloid. J Biol Chem 1994, 269:23403-23406.

34. Falduto M, LaDu MJ, Manelli AM, Getz GS, Puttfarcken PS: Effect of apolipoprotein $\mathrm{E}$ isoforms on b-amyloid induced toxicity in rat primary hippocampal cultures. Soc Neurosci Abst 1995, 21:1716.

35. Castano EM, Prelli F, Pras M, Frangione B: Apolipoprotein E carboxyterminal fragments are complexed to amyloids $\mathrm{A}$ and $\mathrm{L}$. J Biol Chem 1995, 270:17610-17615.

36. Naslund J, Thyberg J, Tjernberg LO, Wernstedt C, Karlstrom AR, Bogdanovic N, Gandy SE, Lannfelt L, Terenius L, Nordstedt C: Characterization of stable complexes involving apolipoprotein $E$ and the amyloid $B$ peptide in Alzheimer's disease brain. Neuron 1995, 15:219-228.

37. Golabek A, Marques MA, Lalowski M, Wisniewski T: Amyloid beta binding proteins in vitro and in normal human cerebrospinal fluid. Neurosci Lett 1995, 191:79-82

38. Golabek AA, Soto C, Vogel T, Wisniewski T: The interaction between apolipoprotein $E$ and Alzheimer's amyloid $\beta$-peptide is dependent on $\beta$-peptide conformation. J Biol Chem 1996, 271:10602-10606.

39. Shuvaev $W$, Siest G: Interaction between human amphipathic apolipoproteins and amyloid beta-peptide: surface plasmon resonance studies. FEBS Lett 1996, 383:9-12.

40. Chan W, Fornwald J, Brawner M, Wetzel R: Native complex formation between apolipoprotein $\mathrm{E}$ isoforms and the Alzheimer's disease peptide A beta. Biochemistry 1996, 35:7123-7130

41. Zhou Z, Smith JD, Greengard P, Gandy S: Alzheimer amyloid-beta peptide forms denaturant-resistant complex with type epsilon 3 but not type epsilon 4 isoform of native apolipoprotein E. Mol Med 1996, 2:175-180.

42. LaDu MJ, Lukens JR, Reardon CA, Getz GS: Association of human, rat, and rabbit apolipoprotein E with beta-amyloid. J Neurosci Res 1997, 49:9-18.

43. Yang DS, Smith JD, Zhou Z, Gandy SE, Martins RN: Characterization of the binding of amyloid-beta peptide to cell culture-derived native apolipoprotein E2, E3, and E4 isoforms and to isoforms from human plasma. J Neurochem 1997, 68:721-725.

44. Aleshkov S, Abraham CR, Zannis Vl: Interaction of nascent ApoE2, ApoE3, and ApoE4 isoforms expressed in mammalian cells with amyloid peptide beta (1-40). Relevance to Alzheimer's disease. Biochem 1997, 36:10571-10580.
45. Pillot T, Goethals M, Vanloo B, Lins L, Brasseur R, Vandekerckhove J, Rosseneu M: Specific modulation of the fusogenic properties of the Alzheimer beta-amyloid peptide by apolipoprotein E isoforms. Euro J Biochem 1997, 243:650-659.

46. Russo C, Angelini G, Dapino D, Piccini A, Piombo G, Schettini G, Chen S, Teller JK, Zaccheo D, Gambetti P. Tabaton M: Opposite roles of apolipoprotein E in normal brains and in Alzheimer's disease. Proc Natl Acad Sci USA 1998, 95:15598-15602

47. Pillot T, Goethals M, Najib J, Labeur C, Lins L, Chambaz J, Brasseur R, Vandekerckhove J, Rosseneu M: Beta-amyloid peptide interacts specifically with the carboxy-terminal domain of human apolipoprotein E: relevance to Alzheimer's disease. J Neurochem 1999, 72:230-237.

48. Yamauchi K, Tozuka M, Nakabayashi T, Sugano M, Hidaka H, Kondo Y, Katsuyama $\mathrm{T}$ : Higher avidity binding of apolipoprotein (E-All) complex than of apolipoprotein E monomer to beta-amyloid. J Neurosci Res 1999, 58:301-307.

49. Aleshkov SB, Li X, Lavrentiadou SN, Zannis VI: Contribution of cysteine 158, the glycosylation site threonine 194, the amino- and carboxy-terminal domains of apolipoprotein $\mathrm{E}$ in the binding to amyloid peptide beta (1-40). Biochemistry 1999, 38:8918-8925.

50. Golabek AA, Kida E, Walus M, Perez C, Wisniewski T, Soto C: Sodium dodecyl sulfate-resistant complexes of Alzheimer's amyloid beta-peptide with the $\mathrm{N}$-terminal, receptor binding domain of apolipoprotein $\mathrm{E}$. Biophys J 2000, 79:1008-1015.

51. Tokuda T, Calero M, Matsubara E, Vidal R, Kumar A, Permanne B, Zlokovic B, Smith JD, LaDu MJ, Rostagno A, et al: Lipidation of apolipoprotein E influences its isoform-specific interaction with Alzheimer's amyloid beta peptides. Biochem J 2000, 348(Pt 2):359-365.

52. Drouet $B$, Fifre A, Pincon-Raymond M, Vandekerckhove J, Rosseneu M, Gueant JL, Chambaz J, Pillot T: ApoE protects cortical neurones against neurotoxicity induced by the non-fibrillar C-terminal domain of the amyloid-beta peptide. J Neurochem 2001, 76:117-127.

53. Zhou Z, Relkin N, Ghiso J, Smith JD, Gandy S: Human cerebrospinal fluid apolipoprotein $\mathrm{E}$ isoforms are apparently inefficient at complexing with synthetic Alzheimer's amyloid-[beta] peptide (A[beta] 1-40) in vitro. Mol Med 2002, 8:376-381.

54. Bentley NM, LaDu MJ, Rajan C, Getz GS, Reardon CA: Apolipoprotein E structural requirements for the formation of SDS-stable complexes with beta-amyloid-(1-40): the role of salt bridges. Biochem J 2002, 366:273-279.

55. Gylys KH, Fein JA, Tan AM, Cole GM: Apolipoprotein E enhances uptake of soluble but not aggregated amyloid-beta protein into synaptic terminals. J Neurochem 2003, 84:1442-1451.

56. Manelli AM, Stine WB, Van Eldik $\sqcup$, LaDu MJ: ApoE and Abeta1-42 interactions: effects of isoform and conformation on structure and function. $J \mathrm{Mo} / \mathrm{Neurosci}$ 2004, 23:235-246.

57. Phu MJ, Hawbecker SK, Narayanaswami V: Fluorescence resonance energy transfer analysis of apolipoprotein E C-terminal domain and amyloid beta peptide (1-42) interaction. J Neurosci Res 2005, 80:877-886.

58. Stratman NC, Castle CK, Taylor BM, Epps DE, Melchior GW, Carter DB: Isoform-specific interactions of human apolipoprotein $\mathrm{E}$ to an intermediate conformation of human Alzheimer amyloid-beta peptide. Chem Phys Lipids 2005, 137:52-61.

59. Morikawa M, Fryer JD, Sullivan PM, Christopher EA, Wahrle SE, DeMattos RB, O'Dell MA, Fagan AM, Lashuel HA, Walz T, et al: Production and characterization of astrocyte-derived human apolipoprotein $\mathrm{E}$ isoforms from immortalized astrocytes and their interactions with amyloid-beta. Neurobiol Dis 2005, 19:66-76.

60. Wellnitz S, Friedlein A, Bonanni C, Anquez V, Goepfert F, Loetscher $H$, Adessi C, Czech C: A $13 \mathrm{kDa}$ carboxy-terminal fragment of ApoE stabilizes Abeta hexamers. J Neurochem 2005, 94:1351-1360.

61. Petrlova J, Hong HS, Bricarello DA, Harishchandra G, Lorigan GA, Jin LW, Voss JC: A differential association of Apolipoprotein $E$ isoforms with the amyloid-beta oligomer in solution. Proteins 2011, 79:402-416.

62. Cerf E, Gustot A, Goormaghtigh E, Ruysschaert JM, Raussens V: High ability of apolipoprotein E4 to stabilize amyloid-beta peptide oligomers, the pathological entities responsible for Alzheimer's disease. FASEB J 2011 25:1585-1595.

63. LaDu MJ, Munson GW, Jungbauer L, Getz GS, Reardon CA, Tai LM, Yu C: Preferential interactions between ApoE-containing lipoproteins and Abeta revealed by a detection method that combines size exclusion chromatography with non-reducing gel-shift. Biochim Biophys ActaMolecular and Cell Biology of Lipids 1821, 2012:295-302. 
64. Ly S, Altman R, Petrlova J, Lin Y, Hilt S, Huser T, Laurence TA, Voss JC: Binding of apolipoprotein $\mathrm{E}$ inhibits the oligomer growth of amyloidbeta peptide in solution as determined by fluorescence cross-correlation spectroscopy. J Biol Chem 2013, 288:11628-11635.

65. Verghese PB, Castellano JM, Garai K, Wang Y, Jiang H, Shah A, Bu G, Frieden C, Holtzman DM: ApoE influences amyloid-beta (Abeta) clearance despite minimal apoE/Abeta association in physiological conditions. Proc Natl Acad Sci U S A 2013, 110:E1807-1816.

66. LaDu MJ, Pederson TM, Frail DE, Reardon CA, Getz GS, Falduto MT: Purification of apolipoprotein $\mathrm{E}$ attenuates isoform-specific binding to beta-amyloid. J Biol Chem 1995, 270:9039-9042.

67. LaDu MJ, Gilligan SM, Lukens JR, Cabana VG, Reardon CA, Van Eldik LJ, Holtzman DM: Nascent astrocyte particles differ from lipoproteins in CSF. J Neurochem 1998, 70:2070-2081.

68. Biere AL, Ostaszewski B, Stimson ER, Hyman BT, Maggio JE, Selkoe DJ: Amyloid beta-peptide is transported on lipoproteins and albumin in human plasma. J Biol Chem 1996, 271:32916-32922.

69. Yamauchi K, Tozuka M, Hidaka H, Nakabayashi T, Sugano M, Kondo Y, Nakagawara A, Katsuyama T: Effect of apolipoprotein All on the interaction of apolipoprotein E with beta-amyloid: some apo(E-All) complexes inhibit the internalization of beta-amyloid in cultures of neuroblastoma cells. J Neurosci Res 2000, 62:608-614.

70. LaDu MJ, Reardon C, Van Eldik L, Fagan AM, Bu G, Holtzman D, Getz GS: Lipoproteins in the central nervous system. Ann N Y Acad Sci 2000 903:167-175.

71. Xu Q, Bernardo A, Walker D, Kanegawa T, Mahley RW, Huang Y: Profile and regulation of apolipoprotein $\mathrm{E}$ (ApoE) expression in the CNS in mice with targeting of green fluorescent protein gene to the ApoE locus. J Neurosci 2006, 26:4985-4994.

72. Carlsson J, Armstrong WW, Reiber H, Felgenhauer K, Seidel D: Clinical relevance of the quantification of apolipoprotein $\mathrm{E}$ in cerebrospinal fluid. Clin Chim Acta 1991, 196:167-176.

73. Hesse C, Larsson H, Fredman P, Minthon L, Andreasen N, Davidsson P, Blennow K: Measurement of apolipoprotein E (apoE) in cerebrospinal fluid. Neurochem Res 2000, 25:511-517.

74. Wahrle SE, Shah AR, Fagan AM, Smemo S, Kauwe JS, Grupe A, Hinrichs A Mayo K, Jiang $H$, Thal $L$, et al: Apolipoprotein E levels in cerebrospinal fluid and the effects of ABCA1 polymorphisms. Mol Neurodegener 2007, 2:7.

75. Fagan AM, Younkin LH, Morris JC, Fryer JD, Cole TG, Younkin SG, Holtzman DM: Differences in the Abeta40/Abeta42 ratio associated with cerebrospinal fluid lipoproteins as a function of apolipoprotein E genotype. Ann Neurol 2000, 48:201-210.

76. Yu C, Youmans KL, LaDu MJ: Proposed mechanism for lipoprotein remodelling in the brain. Biochim Biophys Acta 1801, 2010:819-823.

77. Gong JS, Kobayashi M, Hayashi H, Zou K, Sawamura N, Fujita SC, Yanagisawa K, Michikawa M: Apolipoprotein E (ApoE) isoform-dependent lipid release from astrocytes prepared from human ApoE3 and ApoE4 knock-in mice. J Biol Chem 2002, 277:29919-29926.

78. Riddell DR, Zhou H, Atchison $\mathrm{K}$, Warwick HK, Atkinson PJ, Jefferson J, Xu L, Aschmies S, Kirksey Y, Hu Y, et al: Impact of apolipoprotein E (ApoE) polymorphism on brain ApoE levels. J Neurosci 2008, 28:11445-11453.

79. Wahrle SE, Jiang H, Parsadanian M, Kim J, Li A, Knoten A, Jain S, Hirsch-Reinshagen $V$, Wellington $C L$, Bales $K R$, et al: Overexpression of ABCA1 reduces amyloid deposition in the PDAPP mouse model of Alzheimer disease. J Clin Invest 2008, 118:671-682.

80. Hirsch-Reinshagen V, Maia LF, Burgess BL, Blain JF, Naus KE, Mclsaac SA, Parkinson PF, Chan JY, Tansley GH, Hayden MR, et al: The absence of ABCA1 decreases soluble apoE levels but does not diminish amyloid deposition in two murine models of Alzheimer's disease. J Biol Chem 2005, 280:43243-43256.

81. Wahrle SE, Jiang H, Parsadanian M, Hartman RE, Bales KR, Paul SM, Holtzman DM: Deletion of Abca1 increases Abeta deposition in the PDAPP transgenic mouse model of Alzheimer disease. J Biol Chem 2005, 280:43236-43242.

82. Fitz NF, Cronican AA, Saleem M, Fauq AH, Chapman R, Lefterov I, Koldamova R: Abca1 deficiency affects Alzheimer's disease-like phenotype in human ApoE4 but not in ApoE3-targeted replacement mice. J Neurosci 2012, 32:13125-13136.

83. Youmans KL, Leung S, Zhang J, Maus E, Baysac K, Bu G, Vassar R, Yu C, Ladu MJ: Amyloid-beta42 alters apolipoprotein $E$ solubility in brains of mice with five familial AD mutations. J Neurosci Methods 2011, 196:51-59.
84. Morrow JA, Hatters DM, Lu B, Hochtl P, Oberg KA, Rupp B, Weisgraber KH: Apolipoprotein $\mathrm{E} 4$ forms a molten globule. A potential basis for its association with disease. J Biol Chem 2002, 277:50380-50385.

85. Morrow JA, Segall ML, Lund-Katz S, Phillips MC, Knapp M, Rupp B, Weisgraber $\mathrm{KH}$ : Differences in stability among the human apolipoprotein $\mathrm{E}$ isoforms determined by the amino-terminal domain. Biochemistry 2000, 39:1 1657-11666.

86. de Chaves EP, Narayanaswami V: Apolipoprotein E and cholesterol in aging and disease in the brain. Future Lipidol 2008, 3:505-530.

87. Castellano JM, Kim J, Stewart FR, Jiang H, DeMattos RB, Patterson BW, Fagan AM, Morris JC, Mawuenyega KG, Cruchaga C, et al: Human apoE isoforms differentially regulate brain amyloid-beta peptide clearance. Sci Transl Med 2011, 3:89ra57.

88. Deane R, Sagare A, Hamm K, Parisi M, Lane S, Finn MB, Holtzman DM, Zlokovic BV: apoE isoform-specific disruption of amyloid beta peptide clearance from mouse brain. J Clin Invest 2008, 118:4002-4013.

89. Koistinaho M, Lin S, Wu X, Esterman M, Koger D, Hanson J, Higgs R, Liu F, Malkani S, Bales KR, Paul SM: Apolipoprotein E promotes astrocyte colocalization and degradation of deposited amyloid-beta peptides. Nat Med 2004, 10:719-726.

90. Mandrekar S, Jiang Q, Lee CY, Koenigsknecht-Talboo J, Holtzman DM, Landreth GE: Microglia mediate the clearance of soluble Abeta through fluid phase macropinocytosis. J Neurosci 2009, 29:4252-4262.

91. Basak JM, Verghese PB, Yoon H, Kim J, Holtzman DM: Low-density lipoprotein receptor represents an apolipoprotein E-independent pathway of Abeta uptake and degradation by astrocytes. J Biol Chem 2012, 287:13959-13971.

92. Thal DR: The role of astrocytes in amyloid beta-protein toxicity and clearance Exp Neurol 2012, 236:1-5.

93. Jiang Q, Lee CY, Mandrekar S, Wilkinson B, Cramer P, Zelcer N, Mann K, Lamb B, Willson TM, Collins JL, et al: ApoE promotes the proteolytic degradation of Abeta. Neuron 2008, 58:681-693.

94. Vekrellis K, Ye Z, Qiu WQ, Walsh D, Hartley D, Chesneau V, Rosner MR, Selkoe DJ: Neurons regulate extracellular levels of amyloid beta-protein via proteolysis by insulin-degrading enzyme. J Neurosci 2000, 20:1657-1665.

95. Wirths O, Bayer TA: Intraneuronal Abeta accumulation and neurodegeneration: lessons from transgenic models. Life Sci 2012, 91:1148-1152.

96. Li J, Kanekiyo T, Shinohara M, Zhang Y, LaDu MJ, Xu H, Bu G: Differential regulation of amyloid-beta endocytic trafficking and lysosomal degradation by apolipoprotein E isoforms. J Biol Chem 2012, 287:44593-44601.

97. Bachmeier C, Beaulieu-Abdelahad D, Crawford F, Mullan M, Paris D: Stimulation of the retinoid $X$ receptor facilitates beta-amyloid clearance across the blood-brain barrier. J Mol Neurosci 2013, 49:270-276.

98. Hawkes CA, Sullivan PM, Hands S, Weller RO, Nicoll JA, Carare RO: Disruption of arterial perivascular drainage of amyloid-beta from the brains of mice expressing the human APOE epsilon4 allele. PLoS One 2012, 7:e41636.

99. Nielsen HM, Mulder SD, Belien JA, Musters RJ, Eikelenboom P, Veerhuis R: Astrocytic A beta 1-42 uptake is determined by $A$ beta-aggregation state and the presence of amyloid-associated proteins. Glia 2010, 58:1235-1246.

100. LaFerla FM, Green KN, Oddo S: Intracellular amyloid-beta in Alzheimer's disease. Nat Rev 2007, 8:499-509.

101. Wisniewski T, Frangione B: Apolipoprotein E: a pathological chaperone protein in patients with cerebral and systemic amyloid. Neurosci Lett 1992, 135:235-238

102. Sadowski M, Pankiewicz J, Scholtzova H, Ripellino JA, Li Y, Schmidt SD, Mathews PM, Fryer JD, Holtzman DM, Sigurdsson EM, Wisniewski T: A synthetic peptide blocking the apolipoprotein E/beta-amyloid binding mitigates beta-amyloid toxicity and fibril formation in vitro and reduces beta-amyloid plaques in transgenic mice. Am J Pathol 2004, 165:937-948,

103. Sadowski MJ, Pankiewicz J, Scholtzova H, Mehta PD, Prelli F, Quartermain D, Wisniewski T: Blocking the apolipoprotein E/amyloid-beta interaction as a potential therapeutic approach for Alzheimer's disease. Proc Natl Acad Sci U S A 2006, 103:18787-18792.

104. Lourenco MV, Ledo JH: Targeting Alzheimer's pathology through PPARgamma signaling: modulation of microglial function. J Neurosci 2013, 33:5083-5084.

105. Mandrekar-Colucci S, Karlo JC, Landreth GE: Mechanisms underlying the rapid peroxisome proliferator-activated receptor-gamma-mediated amyloid clearance and reversal of cognitive deficits in a murine model of Alzheimer's disease. J Neurosci 2012, 32:10117-10128.

106. Yamanaka M, Ishikawa T, Griep A, Axt D, Kummer MP, Heneka MT: PPARgamma/ RXRalpha-induced and CD36-mediated microglial amyloid-beta phagocytosis 
results in cognitive improvement in amyloid precursor protein/presenilin 1 mice. J Neurosci 2012, 32:17321-17331.

107. Viennois E, Mouzat K, Dufour J, Morel L, Lobaccaro JM, Baron S: Selective liver $\mathrm{X}$ receptor modulators (SLiMs): what use in human health? Mol Cell Endocrinol 2012, 351:129-141.

108. Fitz NF, Cronican AA, Lefterov I, Koldamova R: Comment on "ApoEdirected therapeutics rapidly clear beta-amyloid and reverse deficits in AD mouse models". Science 2013, 340:924.

109. Price AR, Xu G, Siemienski ZB, Smithson LA, Borchelt DR, Golde TE, Felsenstein KM: Comment on "ApoE-directed therapeutics rapidly clear beta-amyloid and reverse deficits in AD mouse models". Science 2013, 340:924.

110. Tesseur I, Lo AC, Roberfroid A, Dietvorst S, Van Broeck B, Borgers M, Gijsen H, Moechars D, Mercken M, Kemp J, et al: Comment on "ApoE-directed therapeutics rapidly clear beta-amyloid and reverse deficits in $A D$ mouse models". Science 2013, 340:924.

111. Veeraraghavalu K, Zhang C, Miller S, Hefendehl JK, Rajapaksha TW, Ulrich J, Jucker M, Holtzman DM, Tanzi RE, Vassar R, Sisodia SS: Comment on "ApoEdirected therapeutics rapidly clear beta-amyloid and reverse deficits in AD mouse models". Science 2013, 340:924.

112. Cramer PE, Cirrito JR, Wesson DW, Lee CY, Karlo JC, Zinn AE, Casali BT, Restivo JL, Goebel WD, James MJ, et al: ApoE-directed therapeutics rapidly clear beta-amyloid and reverse deficits in $\mathrm{AD}$ mouse models. Science 2012, 335:1503-1506.

113. Hanson AJ, Bayer-Carter JL, Green PS, Montine TJ, Wilkinson CW, Baker LD, Watson GS, Bonner LM, Callaghan M, Leverenz JB, et al: Effect of apolipoprotein E genotype and diet on apolipoprotein E lipidation and amyloid peptides: randomized clinical trial. JAMA Neurol 2013:1-9.

114. Yang J, Ji Y, Mehta P, Bates KA, Sun Y, Wisniewski T: Blocking the apolipoprotein E/amyloid-beta interaction reduces fibrillar vascular amyloid deposition and cerebral microhemorrhages in TgSwDI mice. J Alzheimers Dis 2011, 24:269-285.

doi:10.1186/1750-1326-9-2

Cite this article as: Tai et al: Soluble apoE/A $\beta$ complex: mechanism and therapeutic target for APOE4-induced AD risk. Molecular Neurodegeneration 2014 9:2.

\section{Submit your next manuscript to BioMed Central and take full advantage of:}

- Convenient online submission

- Thorough peer review

- No space constraints or color figure charges

- Immediate publication on acceptance

- Inclusion in PubMed, CAS, Scopus and Google Scholar

- Research which is freely available for redistribution 